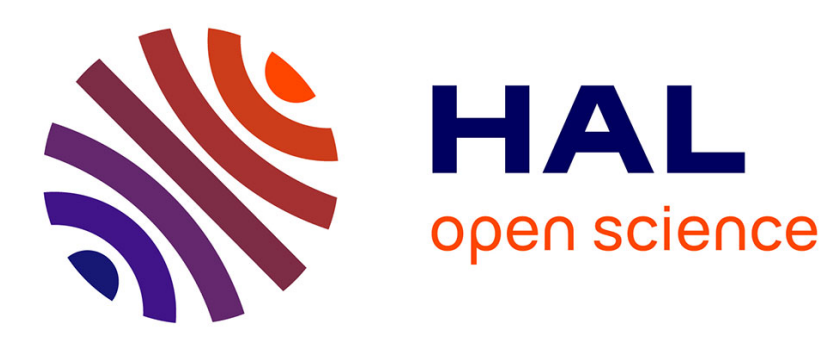

\title{
Sliding Wear of TiN coated 321 stainless steel in CO2 at 300 and $500^{\circ} \mathrm{C}$
}

F. Stott, D. Mitchell

\section{To cite this version:}

F. Stott, D. Mitchell. Sliding Wear of TiN coated 321 stainless steel in CO2 at 300 and $500^{\circ} \mathrm{C}$. Journal de Physique IV Proceedings, 1993, 03 (C9), pp.C9-971-C9-978. 10.1051/jp4:19939100 · jpa-00252342

\section{HAL Id: jpa-00252342 https://hal.science/jpa-00252342}

Submitted on 1 Jan 1993

HAL is a multi-disciplinary open access archive for the deposit and dissemination of scientific research documents, whether they are published or not. The documents may come from teaching and research institutions in France or abroad, or from public or private research centers.
L'archive ouverte pluridisciplinaire HAL, est destinée au dépôt et à la diffusion de documents scientifiques de niveau recherche, publiés ou non, émanant des établissements d'enseignement et de recherche français ou étrangers, des laboratoires publics ou privés. 


\title{
Sliding wear of TiN coated 321 stainless steel in $\mathrm{CO}_{2}$ at 300 and $500{ }^{\circ} \mathbf{C}$
}

\author{
F.H. Stott and D.R.G. Mitchell( $\left.{ }^{\star}\right)$ \\ Corrosion and Protection Centre, UMIST, Manchester, U.K.
}

\begin{abstract}
Advanced carbon dioxide-cooled nuclear reactor environments can be tribologically hostile, with steel components sliding in contact at high temperatures. Although wearprotective oxides can reduce damage in the steady-state conditions, severe wear can occur in the early stages, particularly at temperatures of 300 to $500{ }^{\circ} \mathrm{C}$, where oxidation rates may be low. In this paper, results are presented of the effects of thin titanium nitride coatings in protecting 321 stainless steel against sliding damage in carbon dioxide at 300 and $500{ }^{\circ} \mathrm{C}$. At $500{ }^{\circ} \mathrm{C}$, the coating prevented the severe wear which occured in the early stages for uncoated specimens and there was a smooth transition from protection by the ceramic coating to protection by the oxide on the substrate, ensuring maintenance of low wear rates and steady friction profiles. At $300^{\circ} \mathrm{C}$, breakdown of the coating was followed by metal-metal contact and a sharp increase in friction and wear rate. This was consistent with the behaviour of uncoated steel where wear-protective oxides were unable to develop under the present conditions at $300^{\circ} \mathrm{C}$. However, pre-oxidation of both coated and uncoated specimens for long periods at higher temperatures improved considerably the wear performance at thus temperature, due to the increased availability of oxide to develop the wear-protective surfaces.
\end{abstract}

\section{Introduction.}

Development of wear-protective oxide "glaze" layers can reduce damage to alloy surfaces during sliding contact at high temperatures [1, 2]. These layers are established by formation, compaction and deformation of oxide debris. However, they may take some time to become effective and prior wear may be considerable, particularly at 300 to $600{ }^{\circ} \mathrm{C}$ [2]. At lower temperatures, such layers may be unable to develop at all while, at higher temperatures, they may be established within a few seconds, depending on the conditions. Thus, there is interest in protecting alloy surfaces against wear at temperatures to $600^{\circ} \mathrm{C}$ in the period prior to establishment of the wear-protective "glaze" layers.

In the present research, a study has been made of the resistance of 321 stainless steel to sliding wear in simulated advanced gas-cooled reactor environments where wear can be a major factor in causing material damage in this critical temperature range. Since thin ceramic coatings can give protection against wear at low temperatures [3], they were used in an attempt to reduce wear damage in the early stages. Emphasis has been placed on titanium nitride coatings since these oxidize to some extent at elevated temperatures, thereby, possibly, facilitating establishment of the oxide "glaze" layer. In this paper, the wear behaviour of the coated components is compared with that of uncoated components during sliding at 300 and $500{ }^{\circ} \mathrm{C}$. In addition, in order to facilitate establishment of the oxide "glaze" layers, some

$\left(^{\star}\right)$ Present address: School of Materials Science and Engineering, University of New South Wales, Australia. 
specimens were pre-oxidized in simulated advanced gas-cooled reactor environments prior to sliding.

\section{Experimental.}

The specimens were $10 \mathrm{~mm}$ diameter pins $(30 \mathrm{~mm}$ in length), with hemispherical ends of $50 \mathrm{~mm}$ radius, and $25 \mathrm{~mm}$ diameter discs ( $3 \mathrm{~mm}$ thickness). Both types were machined from bar of 321 stainless steel $(18.3 \mathrm{wt} \% \mathrm{Cr}, 8.1 \% \mathrm{Ni}, 1.1 \% \mathrm{Mn}, 0.6 \mathrm{Ti}, 0.4 \% \mathrm{Si}, 0.1 \% \mathrm{Mo}$, balance $\mathrm{Fe})$. The discs were abraded while the hemispherical surfaces of the pins were ground to the required surface finishes $(0.35 \mu \mathrm{m}$ centre line average in both cases $)$. An arc-evaporative physical vapour deposition process was used to deposit a 2 to $3 \mu \mathrm{m}$ thick adherent and columnar layer of titanium nitride on the contacting surfaces of both types of specimen.

Experiments were undertaken in a reciprocating friction and wear machine, under environmental control. For a test, a pin specimen was secured, with the hemispherical end placed in contact with a disc specimen, under a load of $16.3 \mathrm{~N}$. The wear was achieved by a backwards-and-forwards motion of the disc specimen with a peak-to-peak amplitude of $4.8 \mathrm{~mm}$ at a frequency of $1 \mathrm{~Hz}$. Thus, the disc slid against the stationary pin. The specimens were surrounded by heating elements in a sealed enclosure, enabling tests to be carried out in a controlled gaseous environment at 20 to $750( \pm 5)^{\circ} \mathrm{C}$. In the present research, the environment was carbon dioxide at 300 and $500^{\circ} \mathrm{C}$.

The specimens were degreased and secured in the wear apparatus. The system was flushed with de-oxygenated carbon dioxide. When the steady-state environment was attained and the exhaust gas from the apparatus contained about $400 \mathrm{ppm}$ water vapour and $<30$ ppm oxygen, the furnace was switched on until the system attained the required temperature. Sliding was commenced. After the test, the furnace and motor were switched off and the specimens allowed to cool in the reaction gas. The coefficient of friction and contact resistance were monitored continuously by means of a strain-gauge system and a contact-resistance device respectively. The specific wear coefficients were calculated from wear volumes measured by profilometry.

In addition, some pins and discs were preoxidized prior to the tests. Here, the specimens were exposed to a simulated AGR environment of carbon dioxide, $1 \%$ carbon monoxide and 400 to $600 \mathrm{ppm}$ water vapour at $3.1 \mathrm{MN} \mathrm{m}^{-2}$ in autoclaves at 550 or $700^{\circ} \mathrm{C}$ for up to $10000 \mathrm{~h}$, with cool-to-room-temperature cycles every 1000 to $1500 \mathrm{~h}$. The specimens were cooled in the reaction gas and used in some of the wear tests.

\section{Results and discussion.}

3.1 SLIDING AT $300^{\circ} \mathrm{C}$. - During sliding at $300^{\circ} \mathrm{C}$, the uncoated stainless steel specimens gave relatively high friction values, with very erratic friction traces, particularly in the early stages (Fig. 1a). The contact resistance was always below the detection limit, consistent with metal-metal contact. Specific wear coefficients were typically 3 to $4 \times 10^{-13} \mathrm{~m}^{2} \mathrm{~N}^{-1}$. There was evidence of severe wear and no formation of wear-protective oxides. Deep grooves (Fig. 2a) were typical of metal-metal wear. There was considerable plastic deformation of the surface and much debris was produced, shown by $\mathrm{X}$-ray diffraction to be metallic and magnetite particles.

The friction versus time plot for the coated steel specimens at $300^{\circ} \mathrm{C}$ was very different from that for the uncoated specimens (Fig. 1a). There were no irregularities in the trace in the 

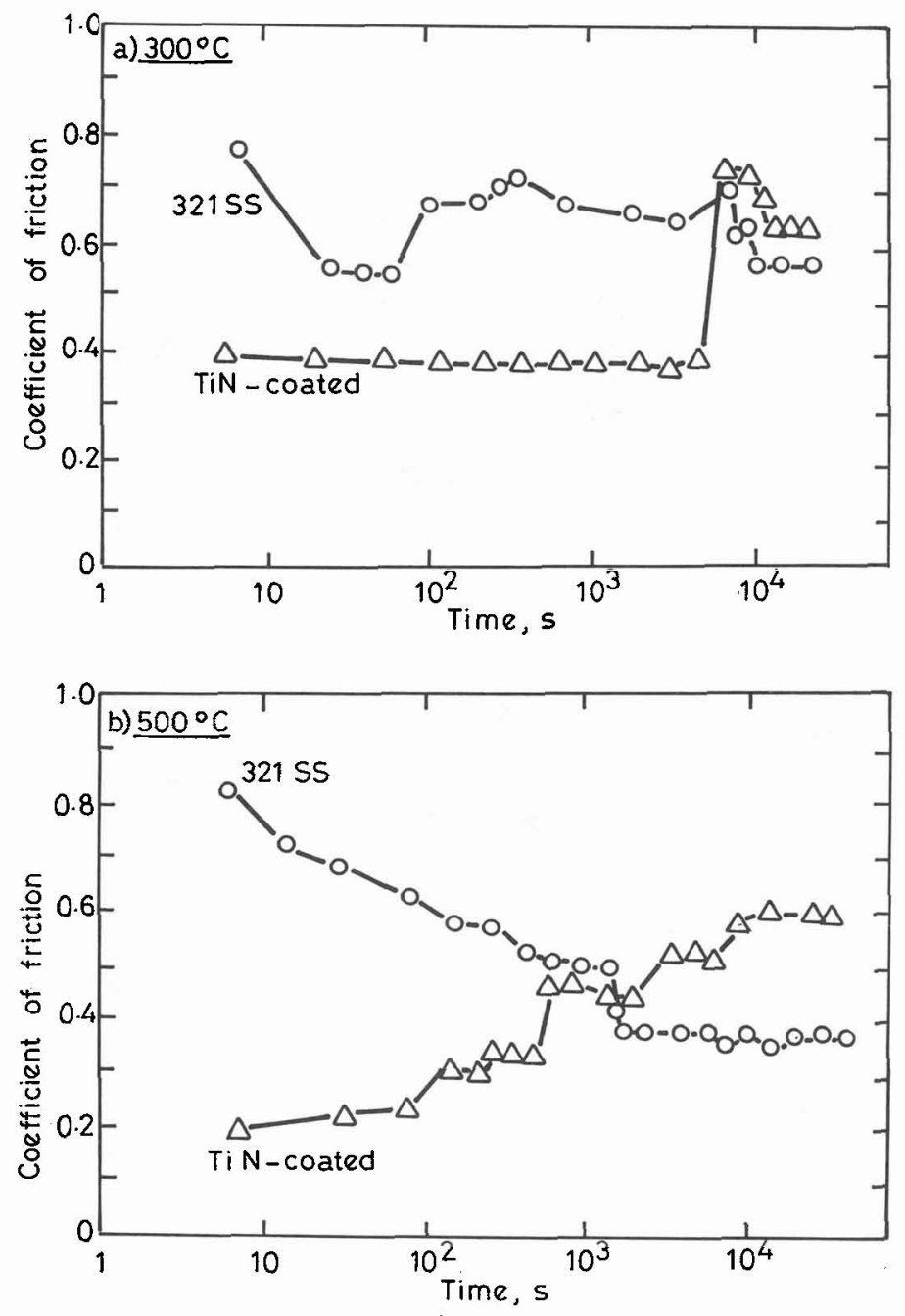

Fig. 1. - Coefficient of friction versus time plots for 321 stainless steel, uncoated and coated with titanium nitride, during like-on-like sliding at 300 and $500{ }^{\circ} \mathrm{C}$.

early stages and a low coefficient of friction was recorded. However, after some time, the friction increased abruptly and sharply to a value of about 0.7 and the trace became very erratic for the remainder of the test. The time of this transition was usually 6000 to $12000 \mathrm{~s}$ after commencement of the test. Small but positive contact resistance values were recorded prior to the transition, but, subsequently, such values could no longer be detected, consistent with failure of the coating at the transition, leading to metal-metal contact. Prior to this time, the coated surface has a polished appearance and little wear occurred. For a test which was terminated just before the transition, the coating was still intact, although it had been thinned sufficiently by the sliding action to have started to break up. There were extensive cracks in the coating, at right angles to the direction of motion (Fig. 2b). For a test which was terminated immediately after the transition, the coating had been broken through in its central region, resulting in severe wear of the underlying alloy (Fig. 2c). After longer 

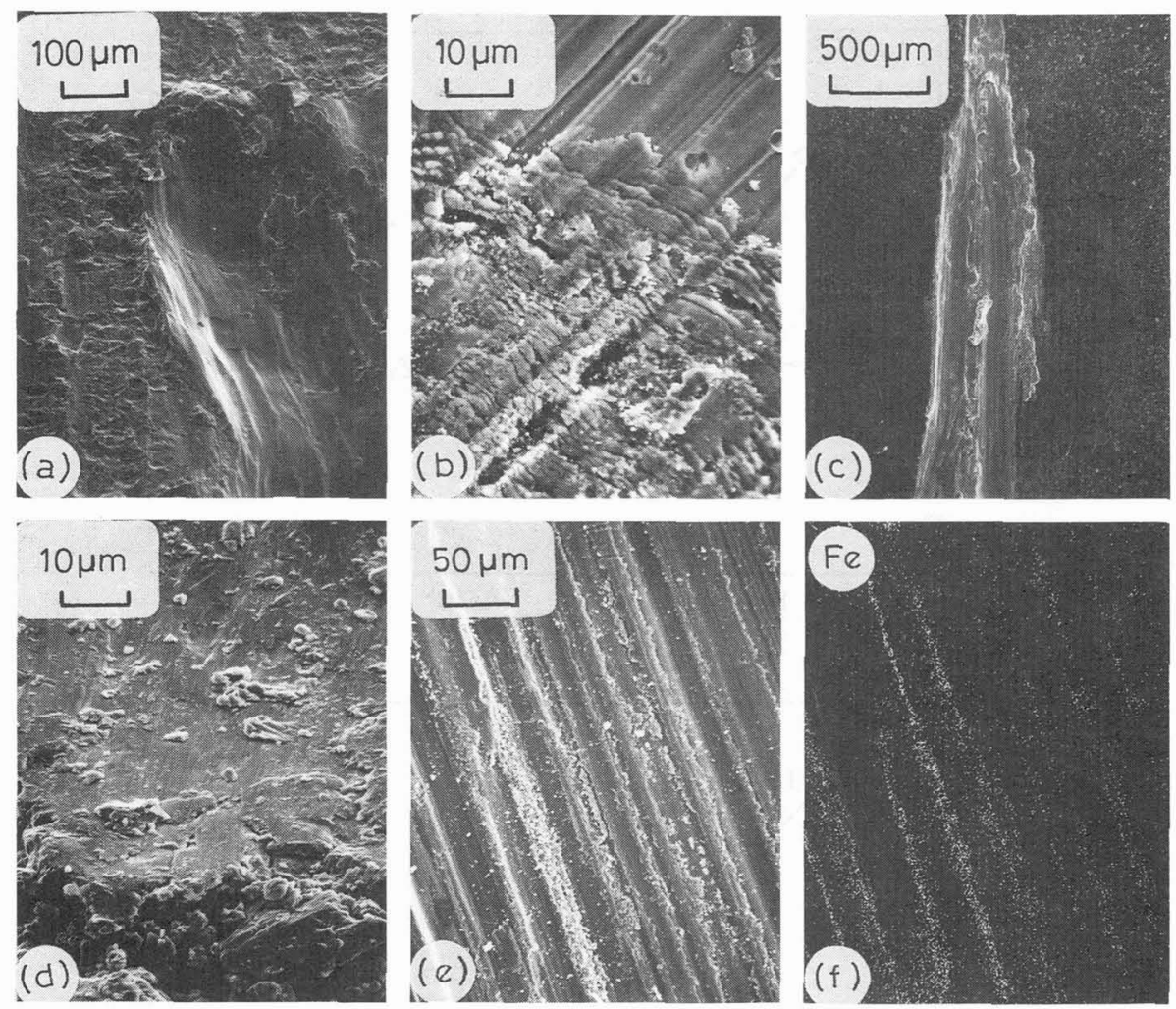

Fig. 2. - Scanning electron micrographs of wear scars formed on discs of 321 stainless steel after sliding for $3 \mathrm{~h}$ at 300 ot $500^{\circ} \mathrm{C}$ : a) At $300^{\circ} \mathrm{C}$, uncoated; b) At $300^{\circ} \mathrm{C}$, coated, before friction transition; c) At $300^{\circ} \mathrm{C}$, coated, immediately after friction transition; d) At $500^{\circ} \mathrm{C}$, uncoated; e) At $500^{\circ} \mathrm{C}$, coated; f) At $500^{\circ} \mathrm{C}$, coated, Fe X-ray map of e).

times, the wear scars were very similar to those of the uncoated specimens, with extensive deformation and ploughing of the alloy substrate and no residual coating in the wear scar.

The coating has very good adhesion to the substrate and failure results from progressive thinning of the ceramic until fracture and penetration can occur. Once metal-metal or metal-ceramic contact is established, the increased adhesion between the contacting surfaces facilitates rapid removal of the adjacent thinner and fractured coating, leading to rapid wear rates. The specific wear coefficient, calculated assuming that all the wear occurred after the transition, was very similar to that for the uncoated specimens.

Thus, oxidation has little role in the wear of coated or uncoated specimens at $300^{\circ} \mathrm{C}$ under these conditions.

3.2 SLIDING AT $500{ }^{\circ} \mathrm{C}$. - Here, the friction versus time traces were different from those recorded at $300^{\circ} \mathrm{C}$ (Fig. Ib). For the uncoated specimens, the initially high coefficient of friction decreased steadily during the next $1500 \mathrm{~s}$ before decreasing sharply to 0.4 , at which it remained for the rest of the test period, up to $10 \mathrm{~h}$. Although no contact resistance values were recorded in the initial $1500 \mathrm{~s}$, consistent with metal-metal contact, thereafter, positive readings were obtained. Following this sharp drop in friction, the contacting surfaces were covered by patches or islands of very smooth, compacted debris, typical of wear-protective 
oxide "glaze" layers developed on alloys during high-temperature sliding [1, 2]. The surfaces were smooth and highly polished (Fig. 2d). Analysis of such islands in plan gave similar iron, nickel and chromium ratios as in the bulk alloy, together with oxygen. The debris particles from which these regions had developed were typically 1 to $15 \mu \mathrm{m}$ in diameter. $\mathrm{X}$-ray diffraction of loose debris from the wear scars indicated magnetite and oxide-coated alloy particles. The specific wear coefficient $\left(0.6 \times 10^{-13} \mathrm{~m}^{2} \mathrm{~N}^{-1}\right)$ was much less than that following sliding at $300^{\circ} \mathrm{C}$.

Initially, the coefficient of friction was very low for the coated specimens, but increased steadily with time to about 0.6 after $9000 \mathrm{~s}$, at which it remained for the rest of the run (Fig. 1b). No wear was detected, indicating that protection was maintained throughout the test. After several hours, the coating was still intact, but was heavily grooved (Fig. 2e). As shown by an X-ray map for iron, substrate material was present at the base of these grooves (Fig. 2f). However, oxidation of such material prevents metal-metal contact, thereby retaining the effectiveness of the coating in giving wear protection.
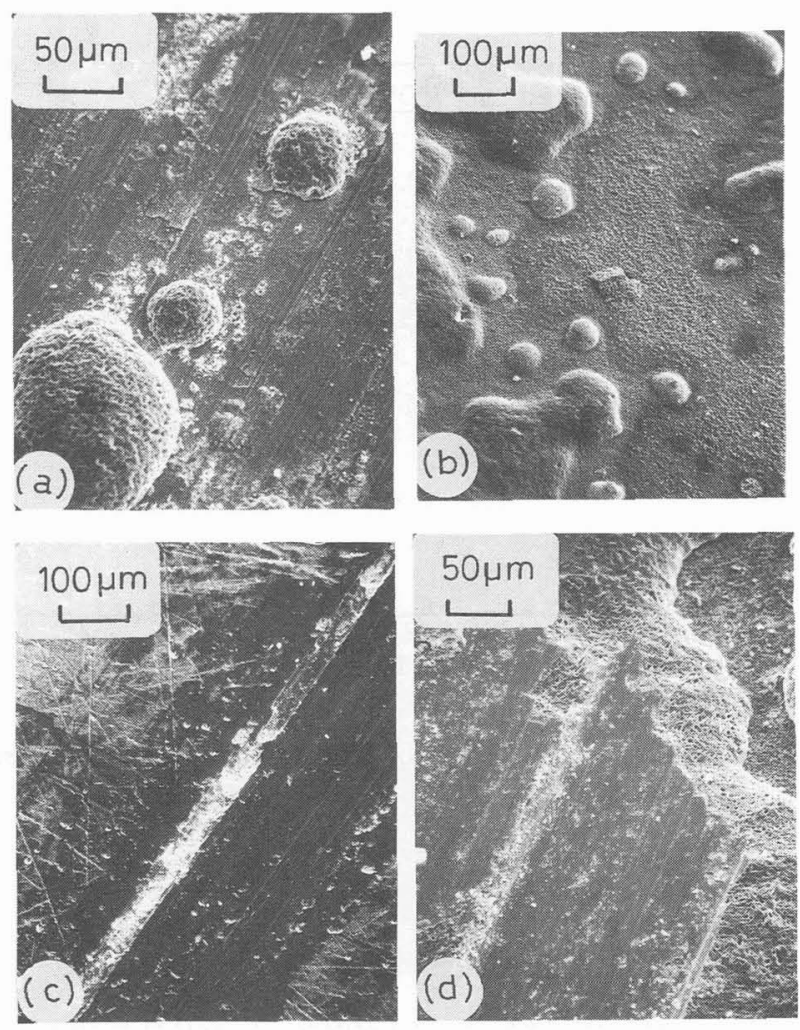

Fig. 3. - Scanning electron micrographs of discs of 321 stainless steel after pre-oxidation in simulated AGR gaseous environment: a) Uncoated, pre-oxidized for $9194 \mathrm{~h}$ at $550^{\circ} \mathrm{C}$; b) Coated, pre-oxidized for $3290 \mathrm{~h}$ at $700^{\circ} \mathrm{C}$; c) Coated, pre-oxidized at $550{ }^{\circ} \mathrm{C}$, after sliding for $3 \mathrm{~h}$ at $300{ }^{\circ} \mathrm{C}$; d) Coated, pre-oxidized at $700^{\circ} \mathrm{C}$, after sliding for $3 \mathrm{~h}$ at $300^{\circ} \mathrm{C}$. 

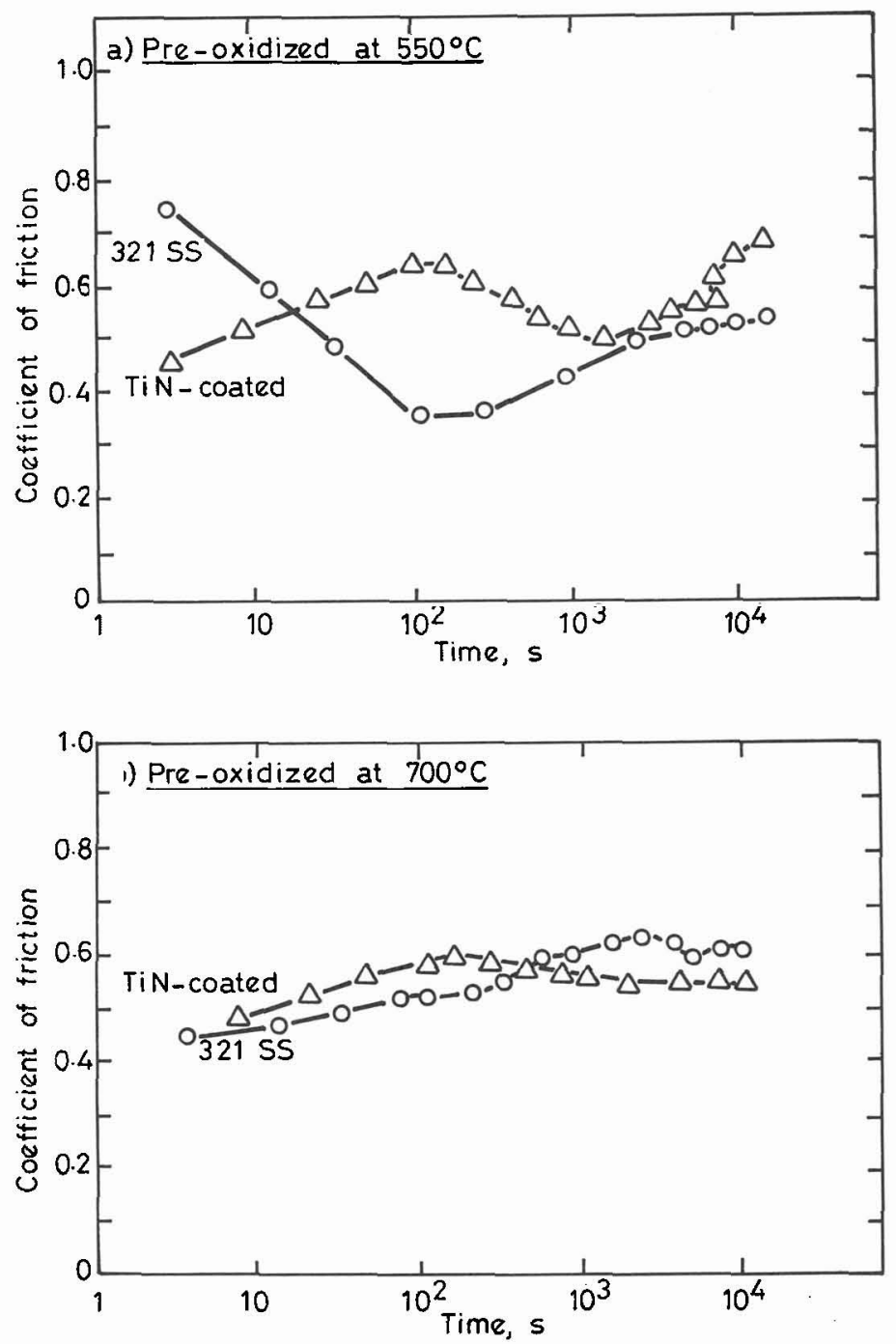

Fig. 4. - Coefficient of friction versus time plots for 321 stainless steel, uncoated and coated with titanium nitride, during like-on-like sliding at $300^{\circ} \mathrm{C}$, following pre-oxidation at 550 and $700{ }^{\circ} \mathrm{C}$.

\section{Effects of pre-oxidation.}

In view of the poor performance of both coated and uncoated specimens at $300^{\circ} \mathrm{C}$, due to the inability to develop wear-protective oxides, an attempt was made to facilitate the establishment of such oxides by a pre-oxidation treatment. Specimens were oxidized at 550 or $700{ }^{\circ} \mathrm{C}$ for long periods in simulated AGR environments. The scales on the uncoated specimens at $550^{\circ} \mathrm{C}$ were generally thin, although thicker oxide nodules, rich in iron, were observed in discrete locations, consistent with breakaway oxidation (Fig. 3a). These nodules developed following localized failure of the chromium-rich oxide scale. X-ray diffraction confirmed that the nodules were essentially magnetite above an iron-chromium-rich oxide region. Sim- 
ilar scales formed at $700^{\circ} \mathrm{C}$, although the nodules were much thicker and more numerous, covering much of the surface. Oxidation of the coated specimens at $550{ }^{\circ} \mathrm{C}$ resulted in development of a thin $(\sim 0.5 \mu \mathrm{m})$ titanium oxide scale. However, at $700{ }^{\circ} \mathrm{C}$, the coating did not have sufficient oxidation resistance and failed extensively. Much of the surface was covered by magnetite-rich nodules, although the surrounding thinner scales did retain some titanium (Fig. 3b).

These pre-oxidation treatments had a beneficial effect on subsequent friction and wear behaviour at $300^{\circ} \mathrm{C}$, by eliminating metal-metal contact in the early stages and supplying oxide to form the compacted, wear-protective "glaze" layer. After pre-oxidation at $550^{\circ} \mathrm{C}$ for 8000 to $10000 \mathrm{~h}$, the coefficient of friction decreased rapidly with time for the uncoated specimens, reaching less than 0.4 after $100 \mathrm{~s}$. Thereafter, the value increased with time but was still relatively low after $3 \mathrm{~h}$ (Fig. 4a). The coefficient of friction was greater for the pre-oxidized coated specimens in the early stages than for the corresponding as-received specimens; subsequently, the value increased, then decreased and, finally, increased to about 0.7 at the end of $3 \mathrm{~h}$ sliding (Fig. $4 \mathrm{a}$ ). However, the trace was very smooth throughout.

The worn surfaces on the uncoated specimens contained numerous regions of wear-protective oxide "glaze". These were at a higher elevation than the surrounding areas and were load-bearing during sliding. They were produced by break up of the pre-formed oxide and compaction and deformation of the debris. The surfaces of the load-bearing regions on the pre-oxidized coated specimens were also very smooth. Moreover, the coating was still intact. Here, a polished surface had formed in the essentially titanium oxide surface which had developed on the coating during pre-oxidation (Fig. 3c).

After pre-oxidation for 3000 to $5000 \mathrm{~h}$ at $700^{\circ} \mathrm{C}$, the coefficients of friction for both coated and uncoated specimens during sliding at $300^{\circ} \mathrm{C}$ were relatively low and very similar to each other (Fig. 4b), as expected following breakdown of the coating during pre-oxidation in the former case. These low values were maintained throughout, consistent with development of a wear-protective oxide "glaze" layer. This was confirmed by examination which revealed an essentially polished surface in that oxide (Fig. 3d), with very little wear.

\section{Conclusions.}

1) High coefficients of friction and severe metallic wear occur during like-on-like reciprocating sliding of 321 stainless steel in carbon dioxide at $300^{\circ} \mathrm{C}$, with deformation and ploughing of the surfaces. A thin ( 2 to $3 \mu \mathrm{m}$ ) titanium nitride coating gives initial protection and results in low friction and wear rates. However, wear causes thinning of the coating until it can break up and much higher friction and wear rates, associated with metal-metal contact, ensue.

2) During sliding at $500^{\circ} \mathrm{C}$, development of a wear-protective oxide layer eventually occurs on the stainless steel, although wear in significant prior to its establishment. A thin titanium nitride coating gives protection to the surfaces in these early stages. Although wear causes thinning of the coating, oxidation of the exposed alloy ensures that low friction and wear are maintained.

3) Long-term exposure of coated and uncoated specimens to carbon dioxide at $550^{\circ} \mathrm{C}$ results in formation of titanium oxide on the former and breakaway iron-rich oxides on the latter. Similar exposures at $700{ }^{\circ} \mathrm{C}$ cause failure of the coating and iron-rich oxides develop on both substrates. During subsequent sliding at $300^{\circ} \mathrm{C}$, these oxides facilitates establishment of wear-protective oxide layers and high wear rates, associated with metal-metal contact, are avoided. 


\section{Acknowledgements.}

The authors thank the Science and Engineering Research Council for a Research Studentship (to DRGM) and Nuclear Electric, particularly Dr. T.C. Chivers and Dr. J. Skinner, for support under the CASE scheme.

\section{References}

[1] Glascott J., Stott F.H., Wood G.C., Oxid. Met. 24 (1985) 99.

[2] LiN D.S., STOTT F.H., WoOD G.C., ASME Trans. 17 (1973) 251.

[3] HAMEL E.S., Mater. Eng. 103 (1986) 8. 